\title{
THE IMPORTANCE OF THE WORLD KIDNEY DAY WORLD KIDNEY DAY - 11 MARCH 2021 - LIVING WELL WITH KIDNEY DISEASE
}

\author{
Momir H. Polenakovic ${ }^{1}$, Saso Dohcev ${ }^{2}$, \\ Irena Rambabova-Bushljetik ${ }^{3}$, Dusko Gjorgjievski ${ }^{4}$, Goce Spasovski ${ }^{3}$
}

\author{
${ }^{1}$ Macedonian Academy of Sciences and Arts Skopje, N. Macedonia \\ ${ }^{2}$ Department of Urology, Medical Faculty, University of Ss. Cyril and Methodius, Skopje, N. Macedonia \\ ${ }^{3}$ Department of Nephrology, Medical Faculty, University of Ss. Cyril and Methodius, Skopje, N. Macedonia \\ ${ }^{4}$ Association of Renal Patients "Nefron", Skopje
}

Corresponding author: Momir H. Polenakovic, Macedonian Academy of Sciences and Arts, Blvd. Krste Misirkov 2, Skopje, N. Macedonia, e-mail: momir@manu.edu.mk

\section{ABSTRACT}

World Kidney Day (WKD) is a global campaign to raise awareness of the importance of our kidneys to overall health and to reduce the frequency and impact of kidney disease and associated health problems worldwide. Kidney disease is a non-communicable disease (NCD) and currently affects around 850 million people worldwide. One in ten adults has chronic kidney disease (CKD). The global burden of CKD is increasing, and is projected to become the 5th most common cause of years of life lost globally by 2040 . CKD is a major cause of catastrophic health expenditure. The costs of dialysis and transplantation consume $2-3 \%$ of the annual healthcare budget in high-income countries. Crucially, kidney disease can be prevented and progression to end-stage kidney disease can be delayed with appropriate access to basic diagnostics and early treatment. This year World Kidney Day continues to raise awareness of the increasing burden of kidney diseases worldwide and to strive for kidney health for everyone, everywhere. During the pandemic with COVID 19 patients kidneys are also damaged, apart from the respiratory tract and other organs. It can lead to an increase in acute renal failure and consequent chronic kidney insufficiency, as well as number of deaths. Therefore, it is important to evaluate the renal function in each patient with COVID 19 virus. In the Republic of North Macedonia from 2006 to present day nephrologists and other medical personnel devoted to the early diagnosis, prevention and treatment of renal disease have participated in the activities of the World Kidney Day. These activities were supported by the Macedonian Society of Nephrology, Dialysis, Transplantation and Artificial Organs, the Department of Nephrology at the Medical Faculty, the Macedonian Academy of Sciences and Arts, the Government of the Republic of North Macedonia, non-governmental nephrology organizations (NEFRON) and the media. There were lectures and presentation devoted to the various theme of the WKD, publications in journals, as well as activities for examination of the renal function of patients in the medical centers. The activities during the WKD contributed to the improvement of the nephrological protection of the citizens of the Republic of N. Macedonia.

Keywords: World Kidney Day, kidney disease, early diagnosis, prevention, therapy

WKD is a joint initiative of the International Society of Nephrology (ISN) and the International Federation of Kidney Foundation (IFKF) and is endorsed by various professional and patient's organizations, including the American Nephrology Nurses Association (ANNA). WKD is held every year, on the second Thursday of March, starting since 2006.
"Kidney disease is a non-communicable disease (NCD) and currently affects around 850 million people worldwide. One in ten adults has chronic kidney disease (CKD). The global burden of CKD is increasing, and is projected to become the 5th most common cause of years of life lost globally by 2040 . CKD is a major cause of catastrophic health expenditure. The costs of dialysis 
and transplantation consume $2-3 \%$ of the annual healthcare budget in high-income countries. Crucially, kidney disease can be prevented and progression to end-stage kidney disease can be delayed with appropriate access to basic diagnostics and early treatment. This year World Kidney Day continues to raise awareness of the increasing burden of kidney diseases worldwide and to strive for kidney health for everyone, everywhere" [2].

During the pandemic with COVID 19 patients kidneys are also damaged, apart from the respiratory tract and other organs. It can lead to an increase in acute renal failure and consequent chronic kidney insufficiency, as well as number of deaths $[3,4]$. Therefore, it is important to evaluate the renal function in each patient with COVID 19 virus.

World Kidney Day initiative started in 2006 and has not stopped growing ever since. Every year, the campaign highlights a particular theme.

HISTORY OF WORLD KIDNEY DAY

-2020 Kidney Health for Everyone Everywhere - from Prevention to Detection and Equitable Access to Care

-2019 Kidney Health for Everyone, Everywhere

- 2018 Kidneys \& Women's Health. Include, Value, Empower

-2017 Kidney Disease \& Obesity - Healthy Lifestyle for Healthy Kidneys

-2016 Kidney Disease \& Children - Act Early to Prevent It!

- 2015 Kidney Health for All

-2014 Chronic Kidney Disease (CKD) and aging

-2013 Kidneys for Life - Stop Kidney Attack!

-2012 Donate - Kidneys for Life - Receive

- 2011 Protect your kidneys: Save your heart

-2010 Protect your kidneys: Control diabetes

-2009 Protect your kidneys: Keep your pressure down

-2008 Your amazing kidneys!

-2007 CKD: Common, harmful and treatable

-2006 Are your kidneys OK?

We are enclosing the invitation from the President of ISN, Bill Couser, to Dr. Polenakovic and other medical staff to participate in the activities of the first World Kidney Day, on 9 March 2006 (Fig. 1).

As we mentioned this year World Kidney Day is devoted to Living Well with Kidney Disease.

We enclose the announcement of the Organizer of the World Kidney Day 2021:

"Being diagnosed with kidney disease can be a huge challenge, both for the patients and those people around them. Its diagnosis and management, particularly in advanced stages of kidney disease, impacts severely upon their lives by reducing their, and that of family and friends, ability to participate in everyday activities like work, travel and socializing whilst causing numerous problematic side effects - e.g. fatigue, pain, depression, cognitive impairment, gastrointestinal and sleep problems.

The current status quo in kidney disease management and treatment aims to prolong longevity by preserving, restoring or substituting kidney function and delivering relief from kidney failure regardless of the efficacy for overall kidney disease management. This disease-centric approach may be inadequate as it does not satisfactorily reflect patients' priorities and values. People living with kidney disease tend to, above all, be able to live well, maintain their role and social functioning, whilst maintaining some semblance of normality and a sense of control over their health and wellbeing. The status quo approach also removes patients' agency as they lack meaningful involvement in the management and treatment of their disease. This in turn leads to patients frequently perceiving treatment as being imposed, punitive and out of their control. For patients to be more content, engaged and constructive with regard to their treatment, and thereby improving clinical outcomes, they need to feel that their symptoms are effectively managed and to be intrinsically motivated to become active participants in their treatment. Ensuing life participation is equally important for both patients and their care-partners, as opposed to feeling consumed and constrained by the current approach to treating kidney disease.

The World Kidney Day Steering Committee has declared 2021 the year of "Living Well with Kidney Disease". This has been done in order to both increase education and awareness about effective symptom management and patient empowerment, with the ultimate goal 


\section{ISN \\ International Society of Nephrology}

Qui. Advancing Kephrologly around the Horld

From: Bill Couser, ISN President

To: All ISN members

Dear Dr. Polenakovic

The inaugural World Kidney Day. Thursday March 9, is just a couple of weeks away. I would therefore like to invite you to support this day dedicated to 'Early Detection and Prevention' and personally make a difference.

The International Society of Nephrology (ISN) and the International Federation of Kidney Foundations (IFKF) have jointly launched a World Kidney Day to

- Increase awareness of chronic kidney disease and associated cardiovascula morbidity and mortality, and

- To draw attention to the worldwide need for early detection and prevention of CKD

Each year the day will be held on the second Thursday of March, beginning this year with Thursday March 9, 2006.

Our principal focus for the first World Kidney Day is to raise awareness amongst general physicians and primary healthcare professionals of the role of kidney as a risk marker in related chronic diseases (such as diabetes and cardiovascular diseases) and the pressing need for early detection of any form of kidney impairment.

As renal specialists, and individual members of the ISN, we each have a role to play. You personally, and all of us collectively, can make a difference on Thursday, March 9 and help educate our colleagues. We must aim to raise awareness of the importance of early detection of kidney impairment through systematic urine testing for serum creatinine or urine albumin - particularly in high risk individuals such as those over 50 or those who are obese; those who smoke, who have diabetes (or a history of diabetes in the family) or who have hypertension.

I therefore call upon you to Act Now, and support World Kidney Day. One short face-to-face meeting with at least one general physician or primary healthcare worker in your community and you will 'make a difference'. Visit the World Kidney Day website at www. worldkidneyday.org for more ideas on how you can help, and for a short Fact Sheet to share during your meeting.

The ISN and the IFKF thank you in advance for supporting World Kidney Day (WKD) and helping to combat the ever increasing health and socio-economic crisis of chronic kidney and vascular diseases.

Please let us know about your activities and successes. We will add information to the WKD website and will be featuring campaigns in upcoming issues of the ISN newsletter. You may contact us at: info@worldkidneyday.org.

We also welcome your thoughts and suggestions for future initiatives to support World Kidney Day.

Thank you in advance

Kind regards,

William G. Couser

President

International Society of Nephrology

Global Headquarters

Ave de Tervueren, 300

B-1150 Brussels, Belgium

Tel: $+32-27431546$

Fax: $+32-2-7431550$

E-mail: info@worldkidneyday.org, info@isn-online.org

Web: www.worldkidneyday.org, www.isn-online.org

Fig. 1. 
of encouraging life participation. Whilst effective measures to prevent kidney disease and its progression are important, patients with kidney disease - including those who depend on dialysis and transplantation - and their care-partners should also feel supported, especially during pandemics and other challenging periods, by the concerted efforts of kidney care communities.

The World Kidney Day Steering Committee calls for the inclusion of life participation as a key focus in the care of patients with CKD and as a building block towards delivering the ultimate goal of living well with kidney disease.

\section{Moreover,}

- Patients with CKD and their family members or other care-partners should be empowered to achieve the health outcomes and life goals that are meaningful and important to them. This will require patients to understand their role, to have the necessary knowledge to be able to engage with clinicians in shared decision-making, as well as developing the skills and support for effective self-management.

- We further advocate for strengthened partnership with patients in the development, implementation and evaluation of interventions for practice and policy settings that enable patients to live well. This needs to be supported by consistent, accessible and meaningful communication.

- We also call for greater emphasis on a strengths-based approach which encompasses strategies to support patient resilience, harness social connections, build patient awareness and knowledge, facilitate access to support, and establish confidence and control in self-management.

- We call for more effective and more integrated and holistic symptom management for all patients with kidney disease beyond traditional kidney therapies including effective strategies to identify and manage symptoms that cause suffering including pain, sleep issues, anxiety, depression, stress, mobility, frailty, and others and ask for more education and management strategies to alleviate these symptoms so that patients and their care-partners can have a better health-related quality of life.

We must move beyond the status quo and advance patient-centeredness in research, practice and policy. Patient empowerment, partnership and improved communications, combined with a paradigm shift towards a strengths-based approach to care, can inspire confidence and hope in patients that they can live well with CKD" [5].

In the Republic of $\mathrm{N}$. Macedonia since 2006 to present day nephrologists and other medical personnel devoted to the early diagnosis, prevention and treatment of renal disease have participated in the activities of the World Kidney Day. These activities were supported by the Macedonian Society of Nephrology, Dialysis, Transplantation and Artificial Organs, the Department of Nephrology at the Medical Faculty, the Macedonian Academy of Sciences and Arts, the Government of the Republic of Macedonia, non-governmental nephrology organizations (NEFRON) and the media. There were lectures and presentation devoted to the various theme of the WKD, publications in journals, as well as activities for examination of the renal function of patients in medical centers.

In the Republic of N. Macedonia the nephrology care is organized by the University Department of Nephrology at the Medical Faculty of the University of Ss. Cyril and Methodius in Skopje, as well as a wellorganized centers for dialysis throughout the whole country. 
Table 1. Centers for dialysis in the Republic of North Macedonia in 2019 [6]

\begin{tabular}{|c|c|c|}
\hline No. & Dialysis Center & Number of patients \\
\hline & Department of Nephrology, Medical Faculty, Skopje & 33 \\
\hline & $\begin{array}{l}\text { Hemodialysis Center, General Hospital " } 8 . \\
\text { September", Skopie }\end{array}$ & 62 \\
\hline & $\begin{array}{l}\text { Special hospital for nephrology and hemodialysis } \\
\text { DIAMED - Gjorche Petrov, Skopje }\end{array}$ & 119 \\
\hline & DIAMED - Zelezara, Skopje & 132 \\
\hline & DIAMED - Vizbegovo, Skopje & 215 \\
\hline & DIAMED - Delchevo & 32 \\
\hline & DIAMED - Gevgelija & 36 \\
\hline & DIAMED - Shtip & 43 \\
\hline & DIAMED - Kochani & 50 \\
\hline & DIAMED - Strumica & 80 \\
\hline & DIAMED - Kumanovo & 84 \\
\hline & DIAMED - Kriva Palanka & 28 \\
\hline & Nephrology Center, Struga & 120 \\
\hline & Peritoneal dialysis & 17 \\
\hline & Home dialysis & 1 \\
\hline & Sistina Nephroplus, Tetovo & 154 \\
\hline & Sistina Nephroplus, Gostivar & 75 \\
\hline & Sistina Nephroplus, Debar & 21 \\
\hline & Sistina Nephroplus, Struga & 15 \\
\hline & Sistina Nephroplus, Ohrid & 40 \\
\hline & Sistina Nephroplus, Kichevo & 32 \\
\hline & Sistina Nephroplus, Bitola & 69 \\
\hline & Sistina Nephroplus, Prilep & 69 \\
\hline & Sistina Nephroplus, Kavadarci & 45 \\
\hline & Sistina Nephroplus, Veles & 47 \\
\hline \multicolumn{2}{|r|}{ TOTAL } & 1619 \\
\hline
\end{tabular}



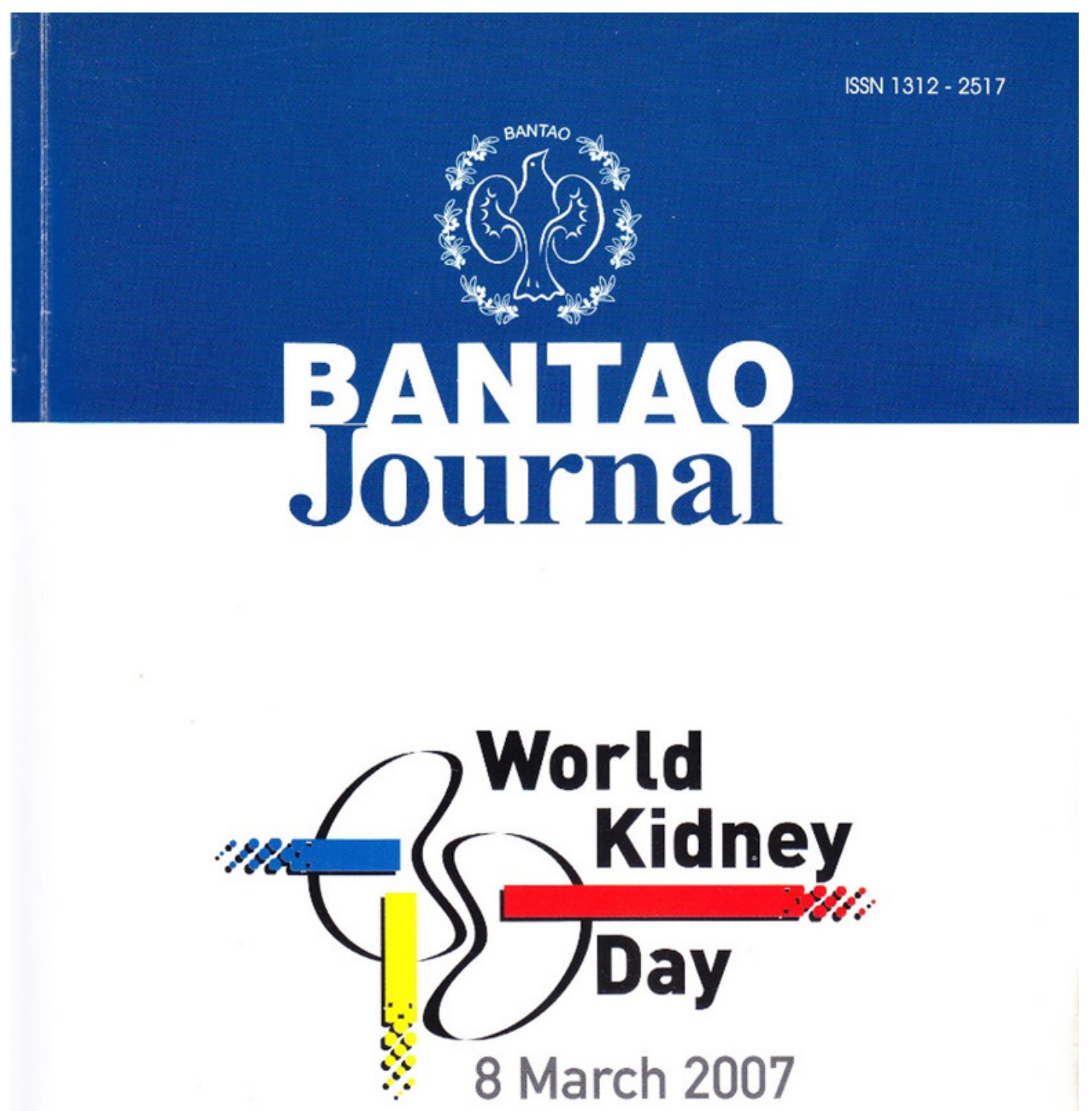

Volume 4 issue 2 December 2006 www.bantao.org

Official Journal of Balkan Cities Association of Nephrology, Dialysis, Transplantation and Artificial Organs

Fig. 2. 
Editorial comments

\section{WHY DO WE NEED A WORLD KIDNEY DAY?}

Newer information and scientific evidence have given persuasive proof that there is more kidney disease than had been thought. Developed countries worldwide treat more than 1.000 .000 individuals yearly and as many as 250.000 new cases each year (1). In the United States and the Netherlands, it is estimated that $6,5 \%$ to $10 \%$ of the general population suffer from some degree of kidney disease and are therefore at increased risk of preventable cardiovascular disease and renal failure. Kidney disease is increasing rapidly in the developing world along with the prevalence of diabetes and hypertension. However, since dialysis and transplantation are both costly procedures, neither is available to the vast majority of people living outside the developed world.

The world needs a kidney day to draw global attention to the increasing global pandemic of kidney and associated cardiovascular disease. Therefore, the International Society of Nephrology (ISN) and the International Federation of Kidney Foundations (IFKF) jointly have proposed that a World Kidney Day (WKD) be established on the second Thursday in March each year. It was launched on Thursday, March 9, 2006, and will be fully inaugurated on Thursday, March 8, 2007. The European Renal Association/European Dialysis and Transplantation Association (ERA/EDTA) has joined this initiative promoting a concept of the European Kidney Health Alliance, as an alliance of patients, professionals and foundations to increase awareness of chronic kidney disease in Europe which is common. harmful and treatable. However, the global aim of the WKD establishment is to broadcast the message about kidney disease to government health officials, general physicians, allied health professionals, individuals and families. In addition, it is an opportunity to demonstrate that a coordinated and successful community effort on behalf of kidney patients can produce positive results so that other national kidney communities can also form similar partnerships and achieve the best results on the respective local and regional levels.

Worldwide, most of the individuals with chronic kidney disease or hypertension are not diagnosed until long after the illness has developed. Moreover, when they are diagnosed. they, too, often are treated suboptimally or not at all. In most parts of the world, once endstage kidney failure occurs, patients do not have access to maintenance hemodialysis treatment or kidney transplantation and simply die.

For these reasons, it is time to speak up and to speak clearly, because the extent and severity of kidney disease has not been appreciated for a long time. Moreover, the availability? of easy methods for early detection and the proven benefits of preventive therapy are not widely known. A day when attention to kidney disease is brought to the world's population is timely. It could also serve as a day to express appreciation for the billions of dollars of support for a disease that currently requires high-technology treatment.

However, as kidney disease is easy to detect with simple, routinely available tests (serum creatinine and urine albumin), both chronic kidney disease and the potential associated cardiovascular complications can be prevented and effectively treated with intensive blood pressure control, glucose control in diabetes patients, liquid-lowering medications, and the use of kidney-protective medication such as angiotensin-converting enzyme inhibitions or angiotensin receptor blockers.

Prevention and slowing the progression of chronic kidney diseases are the only rational public health approaches to addressing the ever-increasing number of patients with end-stage renal disease and reducing the associated cardiovascular risk in these patients $(2,3)$.

The public health mandate is clear for governments: detection and prevention are the most cost-effective methods to address chronic kidney disease and its impact on diabetes and cardiovascular disease. Early referral to nephrologists for more complete assessment of 
intervention, as well as other preventive care measures including influenza vaccinations and pneumococcal vaccinations are needed to reduce hospitalization rates for infections complications that are four times higher in patients suffering from chronic kidney disease (4). Detection efforts center on accurate measurements of serum creatinine and albumin in the urine in the estimating equation to assess the level of kidney disease. Strategies to standardize these measurements should become a global priority.

A World Kidney Day could play an important role in educating physicians and the public about prevention and treatment of kidney disease.

Full imagination of the World Kidney Day will be on March 8, 2007. It will be vital that all nephrologists from the Balkan Peninsula become involved as well as in the whole world.

Media attention, interviews with affected patients, community awareness programs and professional education efforts - they all create awareness that affects public attitudes and behaviors towards prevention and early treatment of the specific disease being profiled.

The kidney disease, with its devastating consequences when left untreated is the one that would benefit from this type of public exposure. The challenge is great, but the promise is even greater: by working together we can achieve a major reduction in the global burden of kidney and cardiovascular disease.

The BANTAO Journal - the official publication of the Balkan Cities Association of Nephrology, Dialysis. Transplantation and Artificial Organs is the main connection between the Balkan Nephrologists, between all members of our Association. We should publish our articles in the BANTAO Journal concerning our experiences in prevention and treatment of kidney disease.

The aim is to publish up to four issues of the Journal and to make the Journal recognizable on the Internet, Medline and Pub Med.

The World Kidney Day is a good event for better action of all nephrologists. The primary purpose of this day is to bring the kidney disease to the forefront as an issue for personal/family health and to provide information about the early symptoms and the simple clinical and laboratory test available for diagnosis.

We must act, and please do act immediately!

We invite you to publish in the BANTAO Journal and to fulfill the ideas of the World Kidney Day - March 8, 2007!

Momir Polenakovic

President of the BANTAO Association

Associated editor of the BANTAO Journal

\section{Goce Spasovski}

Secretary of the BANTAO Association Deputy Editor of the BANTAO Journal ERA/EDTA Ordinary Council Member

References

1. Dirks J.: A world perspective on renal care: The challenges of prevention and treatment. EDTNA ERCA J 2005: $31: 72-74$

2. US Renal Data System: USRDS 2005 Annual Data Report: Atlas of End-Stage Renal Disease in the United States. Bethesda, MD, National Institutes of Health, National Institute of Diabetes and Digestive and Kidney Diseases, 2005

3. Collins AJ, Couser WS, Dirks JH, et al.: Special Announcement World Kidney Day: An Idea Whose Time Has Come. Kidney Int. 2006; 69: 781-782

4. US Renal Data System: USRDS 2004 Annual Data Report: Atlas of End-Stage Renal Disease in the United States. Bethesda. MD, National Institutes of Health, National Institute of Diabetes and Digestive and Kidney Diseases, 2004

Fig. 3. 

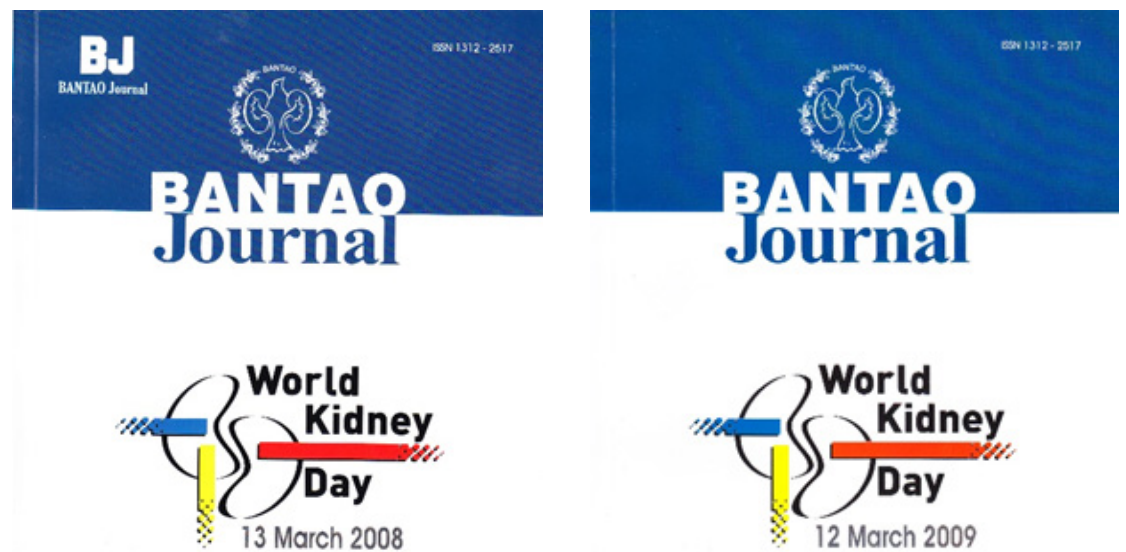

Wolume 5 - lssue 2 - December $2007 \cdot$ mww bantoo.or

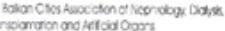

Volume $6 \cdot$ Issue $2 \cdot$ December $2008 \cdot$ mww.bantoo.org

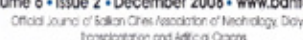
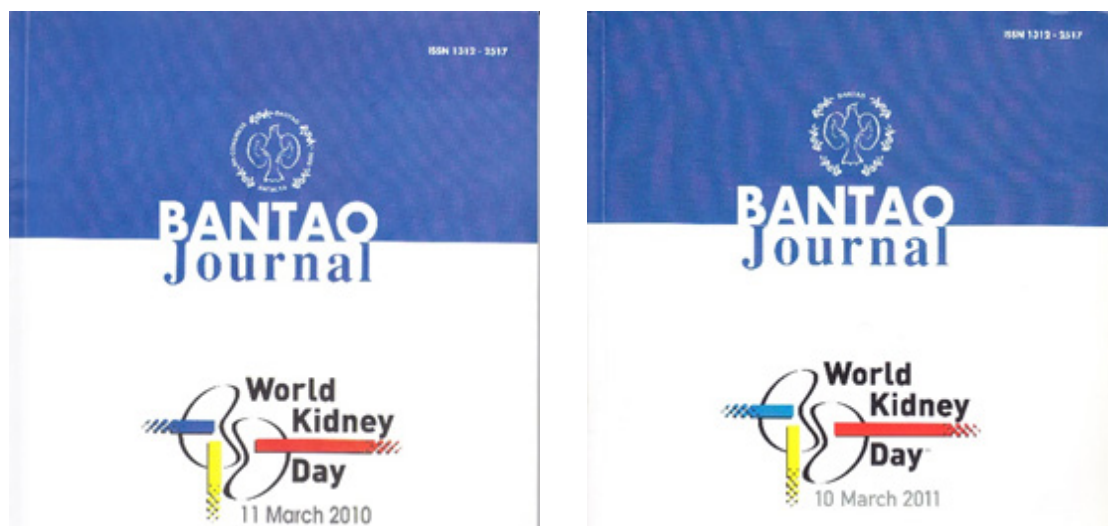

BANTAO Joumel 2008; Volume 7 - huve 1 - Jume 2000
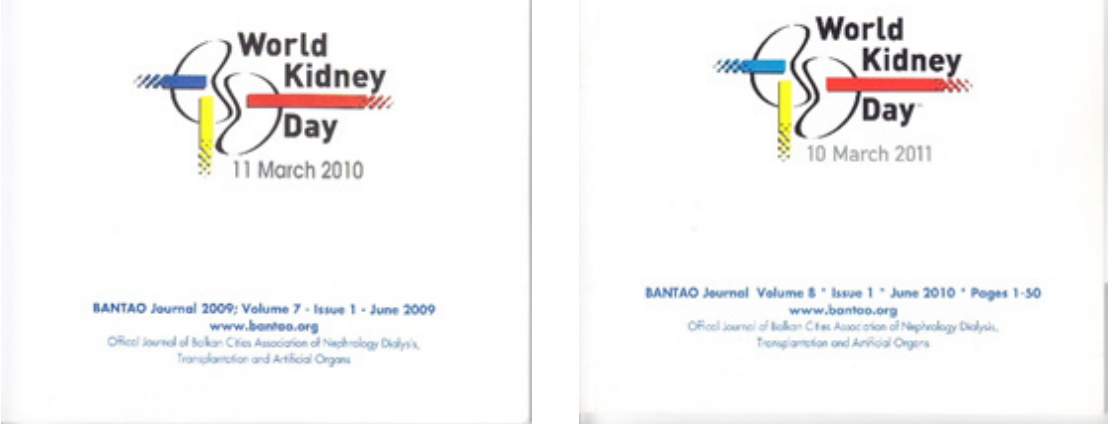

Fig. 4.

Since 2006 when WKD was inaugurated, each year in R. N. Macedonia the idea and the program of the WKD have been regularly realized.

It was occurring in cooperation with the medical workers and citizens to improve the knowledge about the work of the kidney, and the investigations of their function. It has been discussed the possible kidney diseases and especially their early diagnosis, prevention and therapy.

It was also discussed about the association of CKD with hypertension, diabetes mellitus, heart comorbidities, gender, age, obesity, smoking and other factors and disease which can damage kidney and lead to CKD.

Leaflets have been prepared about the kidneys and have been distributed to the medical workers and the citizens. The media have been informing about the importance of the work of the kidney for the whole organism, the association with other organs, and about the early diagnosis of kidney disease and prevention.

Some of the leaflets of the WKD: 

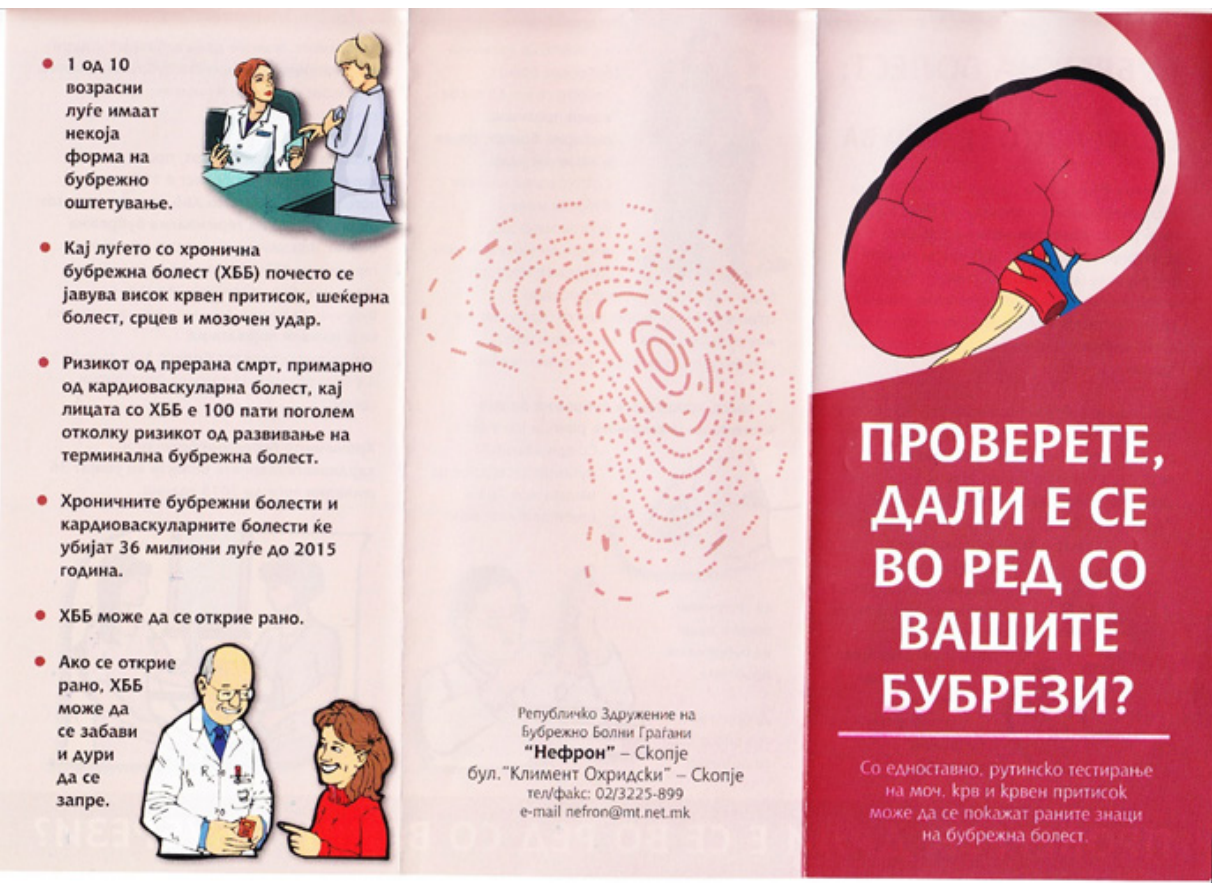

БУБРЕЖНА БОЛЕСТ: ЧЕСТА, ШTETHA,

БОЛЕСТ ШТО СЕ ЛЕКУВА

Главната фупкииіа на нашите бубрези е Аа по отсранат отровите и вишокот на вома од иашата крр. Секој Аен нашите бубрези филтрираат просечно 200 литри на крв! Покрај оваa cekojм⿻евна активност. бубрезите исто тaka nomaraat во контропата на нашиот крвен притисок, во создавањьето на цреените крвни kлетки и ги одрхуваат нашите kосkи зарави

Ako нашите бубрези постепено ја губат нивната способност за фупкциониране. тогаш станува збор за хронична бубрекна болес (XБ5). Toa e "тuaka" 6олест и иecto незабележителна затоа што не мохе да се

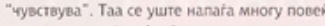
nyfe orkonky wro moxeme Aa

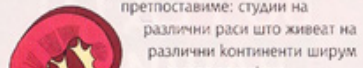
сетот постојано

nokaxyeaza seka 1 OA he 10 возрасни мекоја форма на бубрежно

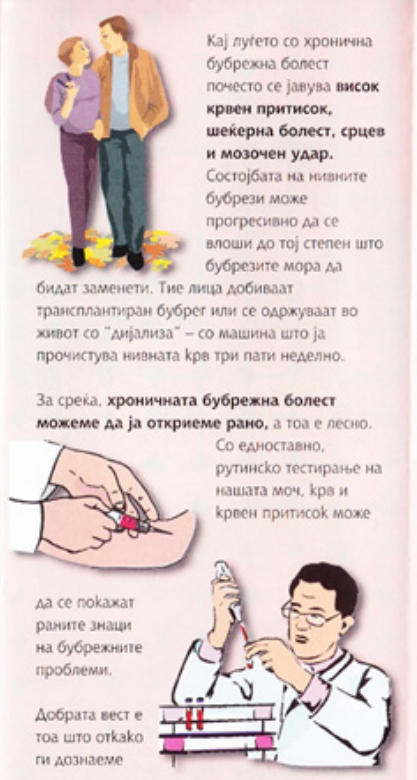

роблемите, мохеме да ја забавиме и Аури с земане на пекови и промена ка неко хивотни навики.

Ризикот ОА прерана смрт, примарно оА карАноваскуларна болест е 100 пати поголем кај лицата со XББ отколку ризико оА разаиване на терминална бубрежна

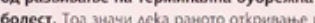
repanuia sanpe pasoojor so kpajpuor casunyu naбубрехната Gonect, ryky ucro raka значителио ке ја намали појавата на

караиоваскуларната болест, koja ненеска е научеста причияе аз прерана сирт ширум свето

Хроничните бубрежни болести и караиоваскуларните болести ке убијат 36 милиони луге АО 2015 гоАина.

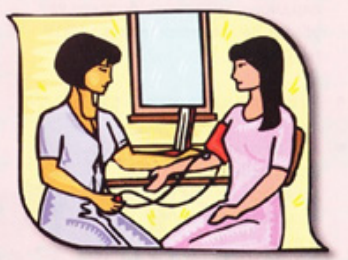

ПРОВЕРЕТЕ, ААЛИ Е СЕ ВО РЕА СО ВАШИТЕ БУБРЕЗИ?

Fig. 5. 

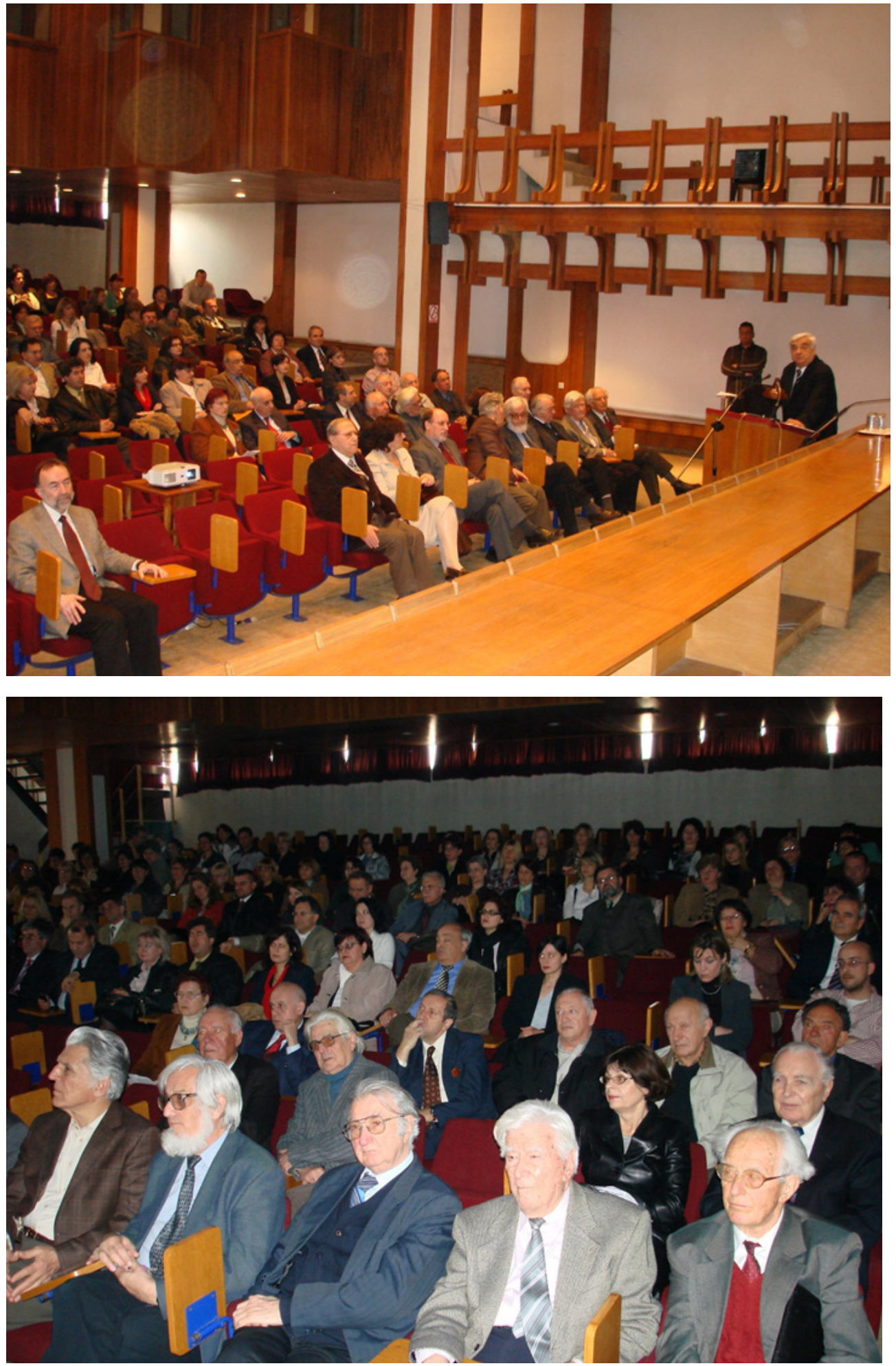

Fig. 6. Participants in the work of the WKD 2007 in the Macedonian Academy of Sciences and Arts, Skopje, R. Macedonia 


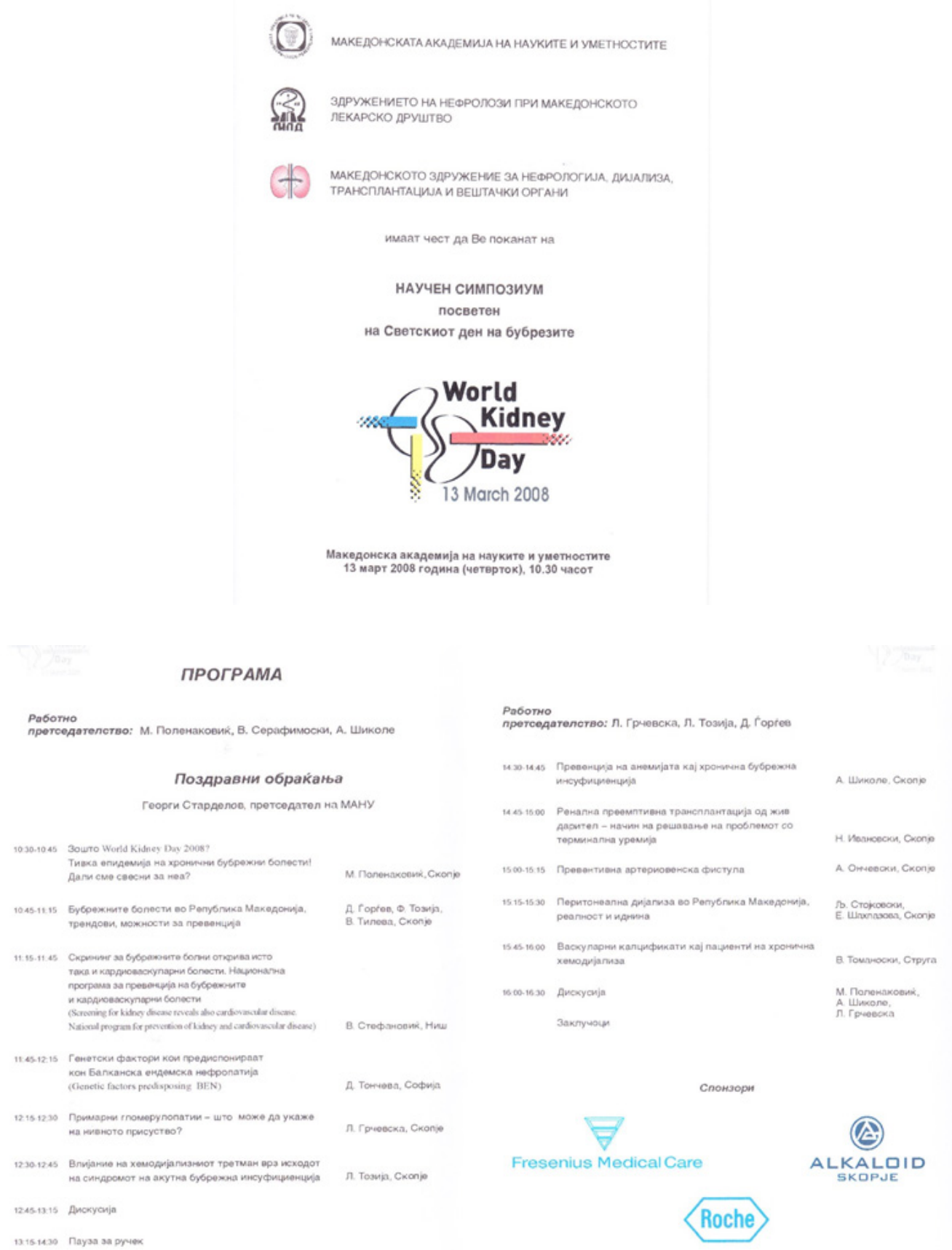

Fig. 7. WKD 2008 


\section{TЕСТИРАЈТЕ СЕ ДАЛИ НОСИТЕ РИЗИК ?}

Дали имате покачен крвен пристисок ?

Дали имате дијабет ?

Дали имате зголемена телесна тежина ?

Дали пушите ?

Дали сте постари од 50 години ?

Дали имате бубрежни болни во фамилијата ?

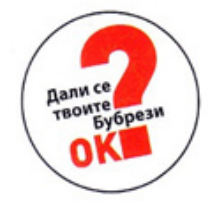

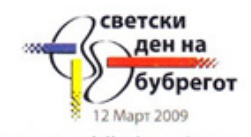

www.worldkidneyday.org

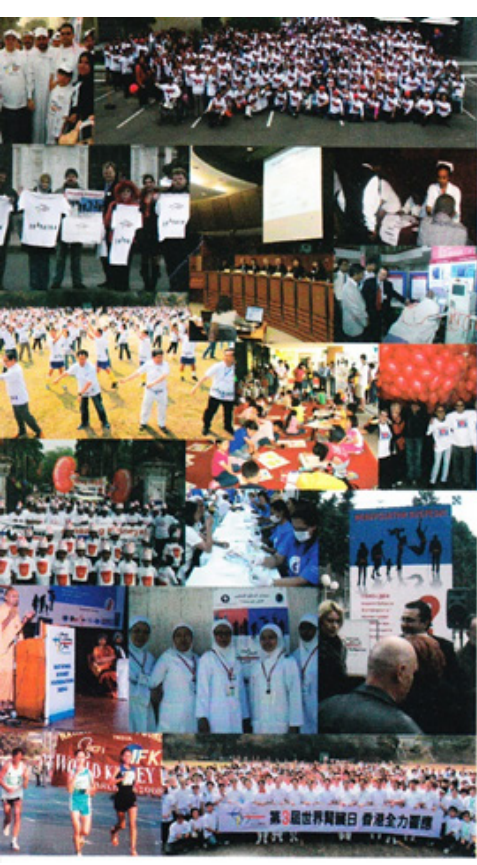

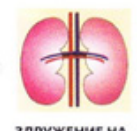

ЗДРУЖЕЕНИЕ НА НЕФРОЛОЗИТЕ НА

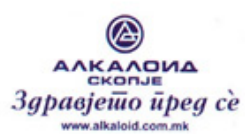

pasjeüo üpeg cè

\section{0 земји на 6 континенти}

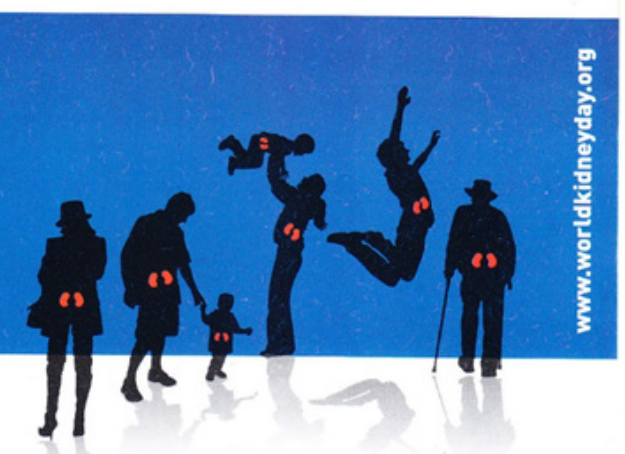

Во акција за здрав бубрег ПРИКЛУЧИ СЕ!

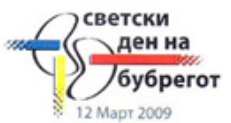

Fig. 8. WKD 2009 
На иничијатиеа на РЗББГ "НЕФРОН", а по повод Сөетсииот ден на бубрегот, Министерството за здравство, на 12.3.2009 година организира акција на бесплатно испитување на нивото на уреа и креатинин во крвта и мерење на крвниот притисокс како превентивна

Сите заиктересирани грағани беслиатни прегледи можат да направат өо спедните установи

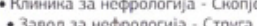

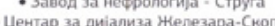

- Цемтрите за диіализа ио: Битола. Велес Гевгелија, Гостияар. Делчево,

Дебар, Каваларии, Кочани, Куманово, Крива Паланке, Прилеп,

Струмица, Тетово и Штип.

Исто така, бесплатни прегледи ќе се вршат и во следните здравствени

- Здравствен дом Берово

Бенски Брон

- заравстеен дом Валалаоео

- Здравствен дом Вевчана

- Здравствен дом Депче

- Заравствен дом Демиар Хисар

- Здравстен дом Кратово

- Здравствен дом Нрушево

- Здравствен дом Неготино

- здравствен дом пехчево

- Злравстрсн дом Пробишти

- Злоравствен дом Ресен

- 3ppascisen доm Pocen

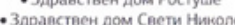

nompouree

W.

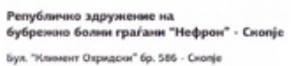

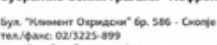

\section{Дали имате висок крвен притисок?}

\section{Бубрегот како причина}

Висониот крвен притисок е една од водечките причини која моме

Бубрезите играат голема улога во

регулација на крениот притисок, а

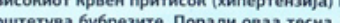

поврзаност, пугето со висок иррен

притисок се ризична група и треба да се

тестираат дали разаиле хроничн

бубренна болест (ХББ).

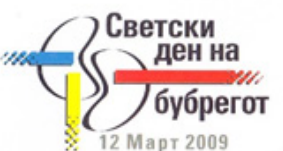

Зошто крвниот притисок е битен при хроничната бубрежна болест (ХББ)?

- Колку е повисон крвниот притисок, толюу снабдуваньето со крв во бурезите е помало. Со тоа струютурата на бубрезите се оштетуөа, а се намалува нивната функција што доведува до ХББ.

- Висониот креен притисок доведува до оштетување на бубрезите, но то

моне да биде ситали и дека оштетуване на бубрезите всќс настанало

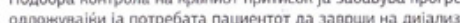

Колку често е застапен високиот крвен притисок?

- Во светот околу еден билион луге имаат висон крвен притисок и тој број

се очекува драматинно да се зголеми на 1.56 билиони до 2025.

- Еден од четири случаи ка целосно откажување на бубрезите е резултат на висом крвен притисок.

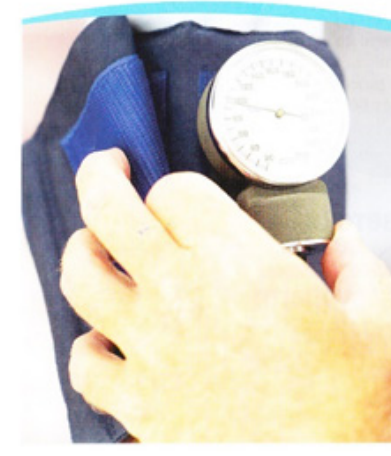

Што се случува со бубрезите кога имате висок крвен

притисок?

- Rora бубрезите се оштетени од висок крвен притисок, тие вейе неможат ефентивно да ја извршуваат својата витална функција - филтрирање на . организмот се јавува состојба на анемија

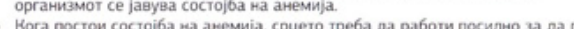
" чувство на замор нај пациентите.

- Ансмијата е директно поврэзна со зголемен ризик од караиоваскуларни заболувања кај пациентите со XББ.

Шrо да направите доколку имате висок крвен притисок? -

маат ХББ тре6а да омена на

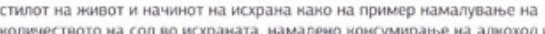
редовни физички венжби

- Доколну пациснтите се придренуразат ні препораките за промена на животииот стил и за редовно земанес на пекарстоа, испитувањьата поканале дена со регулиратье на нреннот притисок се редуцира ризено OA XББ како и ризикот од дијализа или некој мардиоваскуларен настан нано што се сриев или мозочен удар.

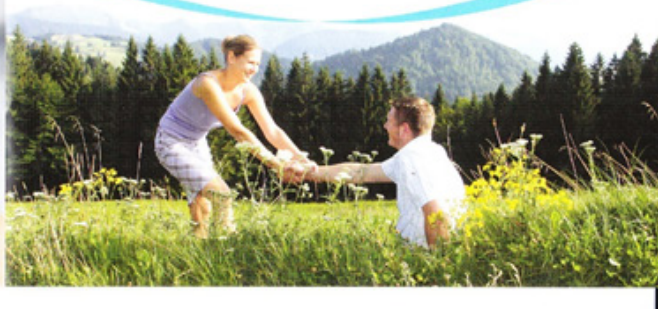

Fig. 9. WKD 2009 
Me inicijativé tê ShRQSV "Nefron", e me rastin e Dités botérore té veshkève, Ministria e shēndetësisề me 12.03 .2009 organizon aksion tè

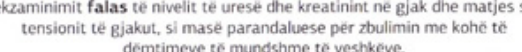

Qytetarèt e interesuar mund tê bejnè kontrollime falas nè institucionet $n$

- Klinika pèr nefrologji - Shku - Entri i nefrologijise - Strugé

- Qendrat pér dijalizê né : Manastir, Veles, Gjevgjeli, Costivar, Dellçevè, Dibér, Kavadar Kogan, Kumanové, Kriva Pallanké, Prilep, Strumicè, Tetoue dhe Shtip.

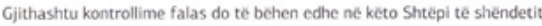

- Shtëpia e shëndetit - Berovie

Shtépia e shendetit - Makedonsk

- Shtepia e shendetit - Vallandowe

- Sheppia e shichdetit vevaan

Shêpia es sendetit - Demir Hisar

- Shtépia e shiendetit - Kratove

- Shtepla e shendetit - Krushevế

- Shtépia e shêndetit - Negotiné

- Shtépia e shendetit - Pchçevé

- Shtêpia e shendetit - Probishtip

- Shtëpia e shêndetit - Radovish

- Shtepia e shendetit - Resnje

- Shitepia e shendetit - Rostushe

- Shtepla e shendetit - Sv. Nikollé

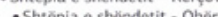

\begin{tabular}{|c|c|}
\hline Nen patronatine & 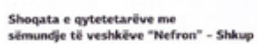 \\
\hline 6 & 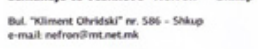 \\
\hline
\end{tabular}

\section{A keni tension të lartë të gjakut?}

Veshka si shkak dhe

viktimë e hipertensionit
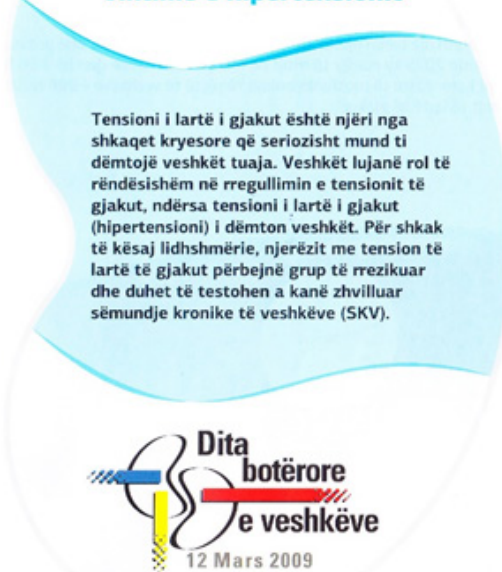

Pse tensioni $i$ lartē $\mathrm{i}$ gjakut ështē $\mathrm{i}$ rëndēsishëm gjatē sëmundjeve kronike të veshkëve ( $\mathrm{SKV}$ )?

Sa me i larte té jeté tensioni i gjakut, furnizimi i veshkève me gjak éshté mè i tyre qé sjell deri te SKV

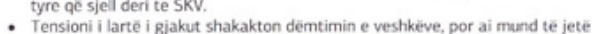

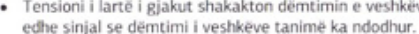

- Kontrollimi mé i miré i tensionit té giakut e ngadalson progresionin e SKV. duke e prolonguar nevojēñ e pacientit pêr dijalizè

Sa shpesh është i përfaqsuar tensioni i lartë i gjakut?

- Ne boté rreth nje bilion njerez kane tension te larte te gjakut dhe pritet qé

deri né vitin 2025 ky numer te mitet ne menyre dramatike deri nè 1.56 bilio

Njè nga kater raste té mosfunksionimit tè plote tè veshkeve èshtè rezultat tensionit tè lartē tê giakut

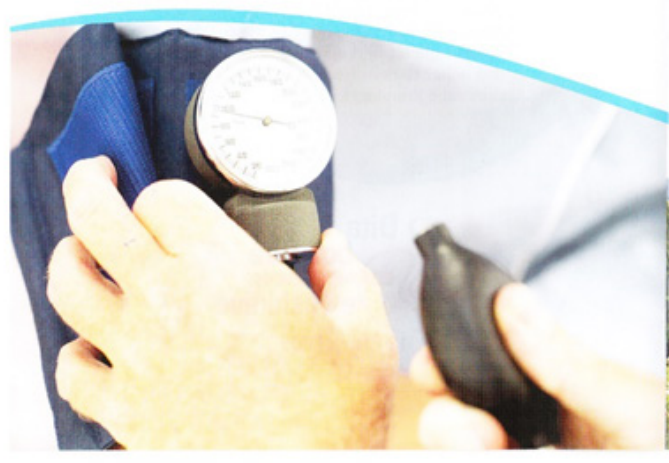

Çfar ndodh me veshkêtt kur kemi tension të lartë tê gjakut?

- Kur veshkèt dèmtohen nga tensioni i larté i gjakut, ato nuk mund nê ményrê panevojshme nga orgionin e tyre vital-fitrimin e materieve dhe lengjeve

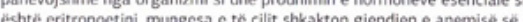
organizmit.

- Kur kemi gjendje të anemisè zemra duhet të punojè mé fortè né mènyrè qê ta

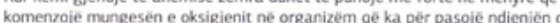
lodhjes.

- Anemia ështé drejtpẹrdrejt e lidhur me ritjen e rrezikut nga sémundje:

kardiovaskulare te pacientét me SKV.

Çfar tẻ bëni nĕse keni tension të lartë të gjakut?

- Pacinetêt qè kanè tension tê larté tè gjakut duhet tè bèine ekzaminime que te

Pacinetêt e rezikuar nga zhvillimi i SKV ose te cilet kané SKV duhet té

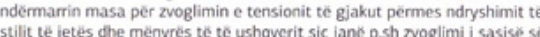
kripes ne ushqim, konsumimi i zvogluar $i$ alkoolit dhe ushtrimet e megullta fizike.

Nese pacinetêt i pêrmbahen rekomandimeve per ndryshimin e stilit të jetus dhe pér manjin e reguilt té barnave, ekzaminimet kane treguar se me regallimin etensionit te gjakut redukohet reziku nga SKV si dhe reziku nga dijaliza dhe mundesia per sum

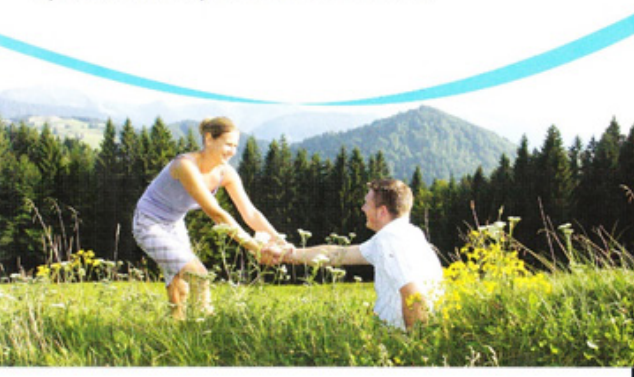

Fig. 10. WKD 2009 


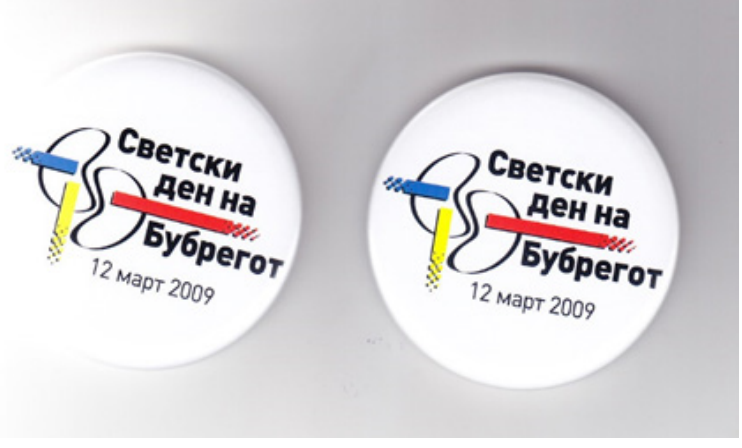

Fig. 11. WKD 2009

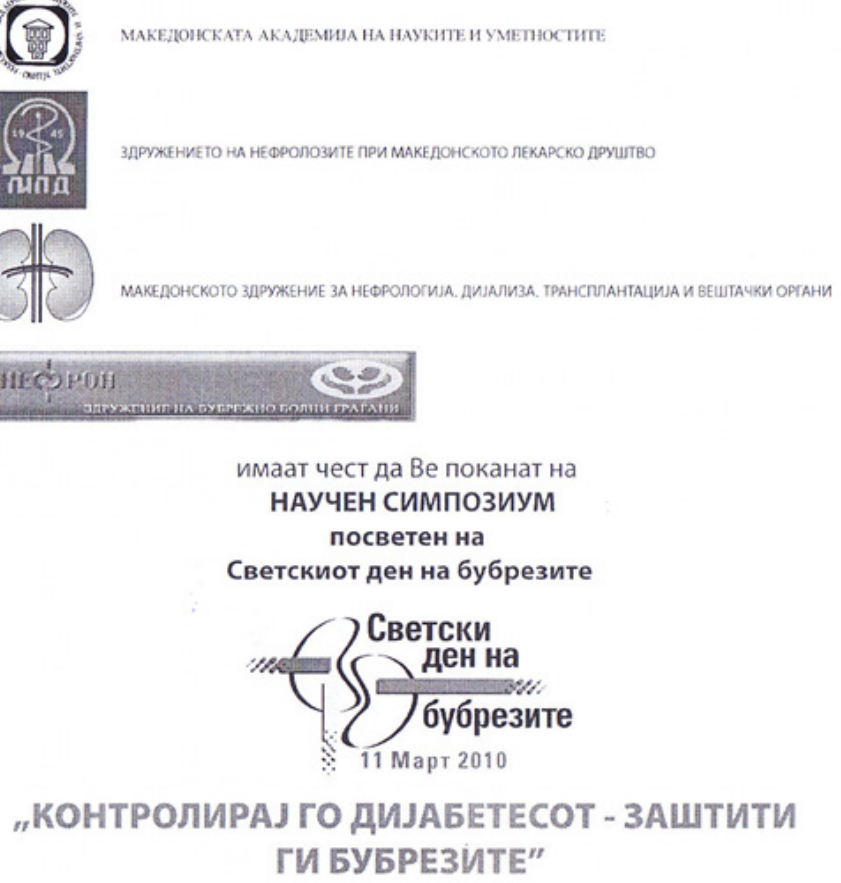

Под покровителство на

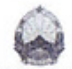

МИНИСТЕРСТВО ЗА ЗАРАВСТВО PETVEAUKA MAKEAOHUJA

Македонска академија на науките и уметностите 11 март 2010 годика (четврток), 11.00 часот

Fig. 12. WKD 2010 

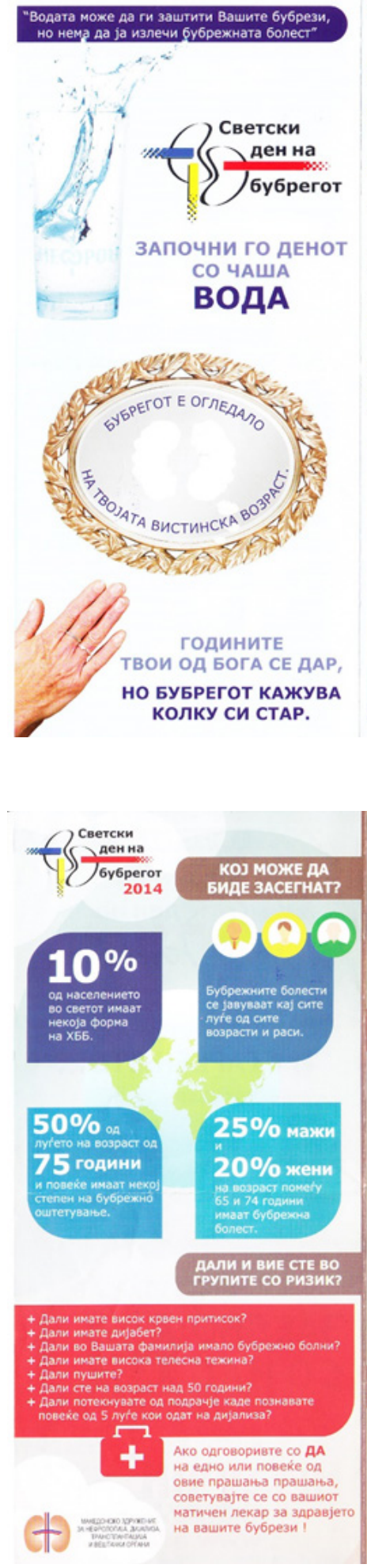

BAЖHO E ДA 3HAEME AEKA:

Раните стадиуми на ХБ5 нсмат симетомй. ХБ5 7ом се појави таa не исчезнува, туку некогаш побрзо

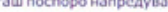

ХББ може да се третира, што порано дознасте дека .

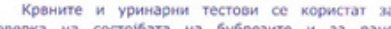
откридаrte на XБ5.

ХББ може да напредува до терминапен стадиум на борекона слабост кој е наречен 5-ти стадиум.

Крајниот 5-ти стадиум па X65 хивотозагрозувачки и бара пекување со Аијализа или
трансплантација. Дијапизата (хемодијапиза или перитонеална) е ророедура на прочистушанье на крета од вишохот на ода и други непожелни состојхи.

Трансплантацијата е кајдобра и кајприродна ретманска процедурз при што на пациентот со ХББ с

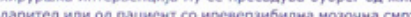
Tr.каравер.

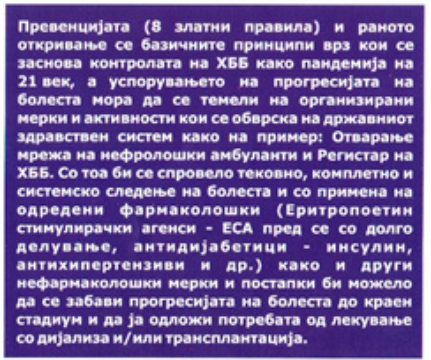

$\because \because 813.03 .2014$

Светски

थ $>$ ден на () бубрегот

ХРОНИЧНА БУБРЕЖНА БОЛЕСТ И СТАРЕЕЊЕТО...

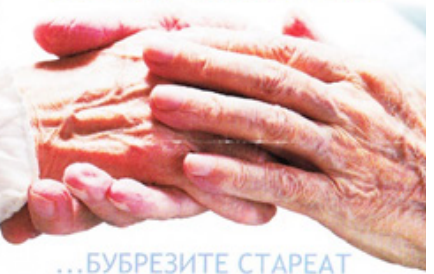

ЗАЕДНО

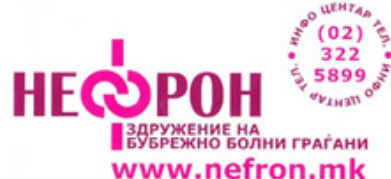

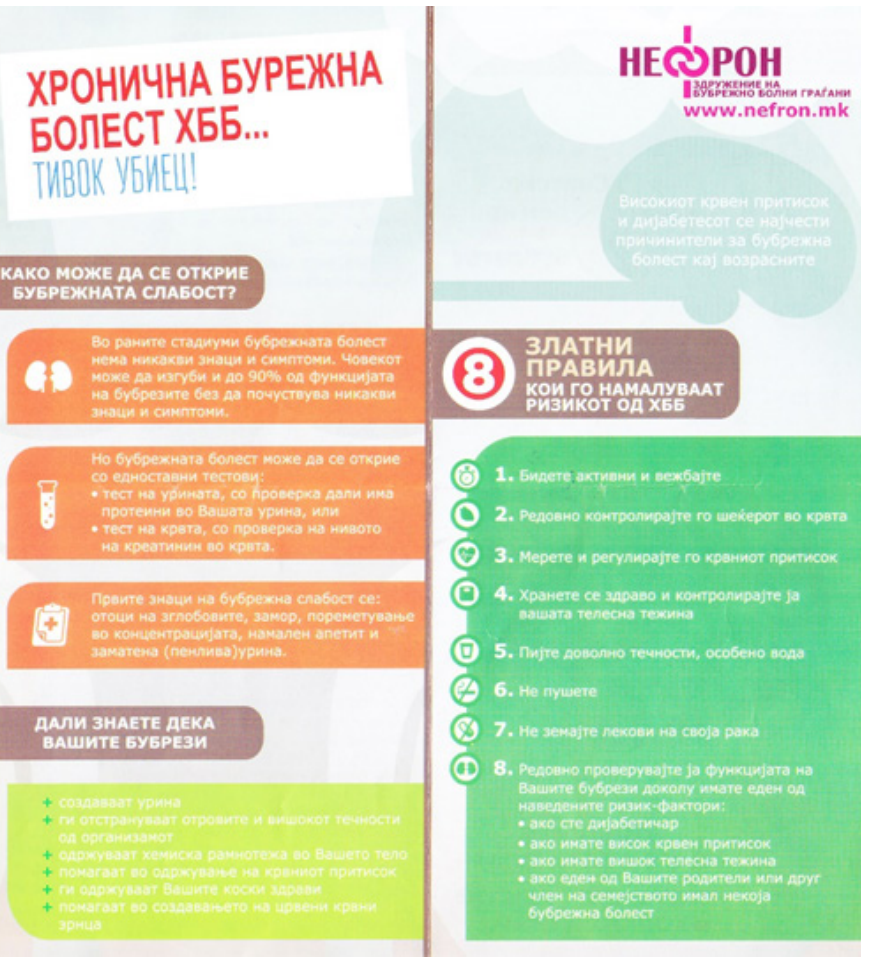

Fig. 13. WKD 2014 


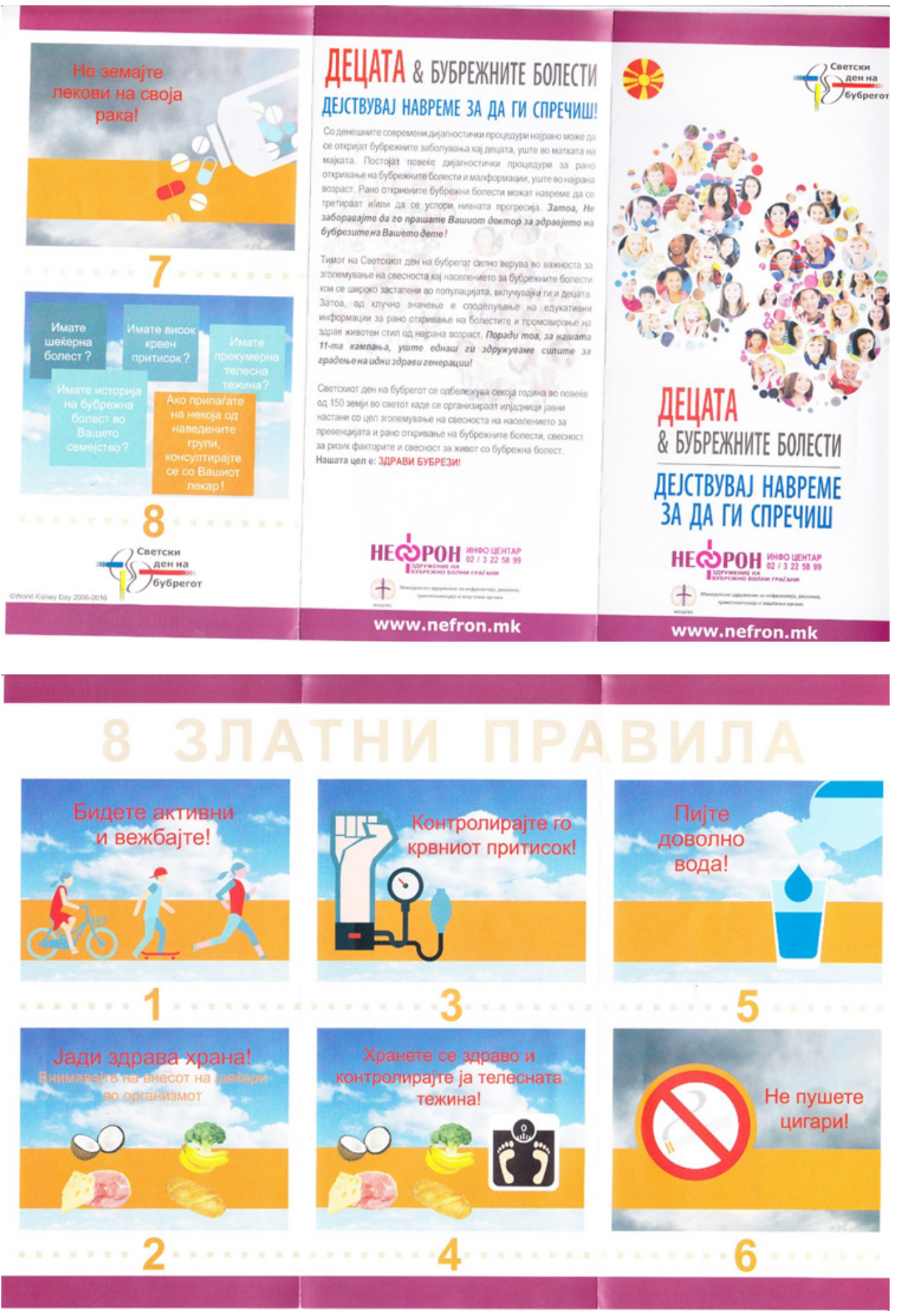

Fig. 14. WKD 2016 


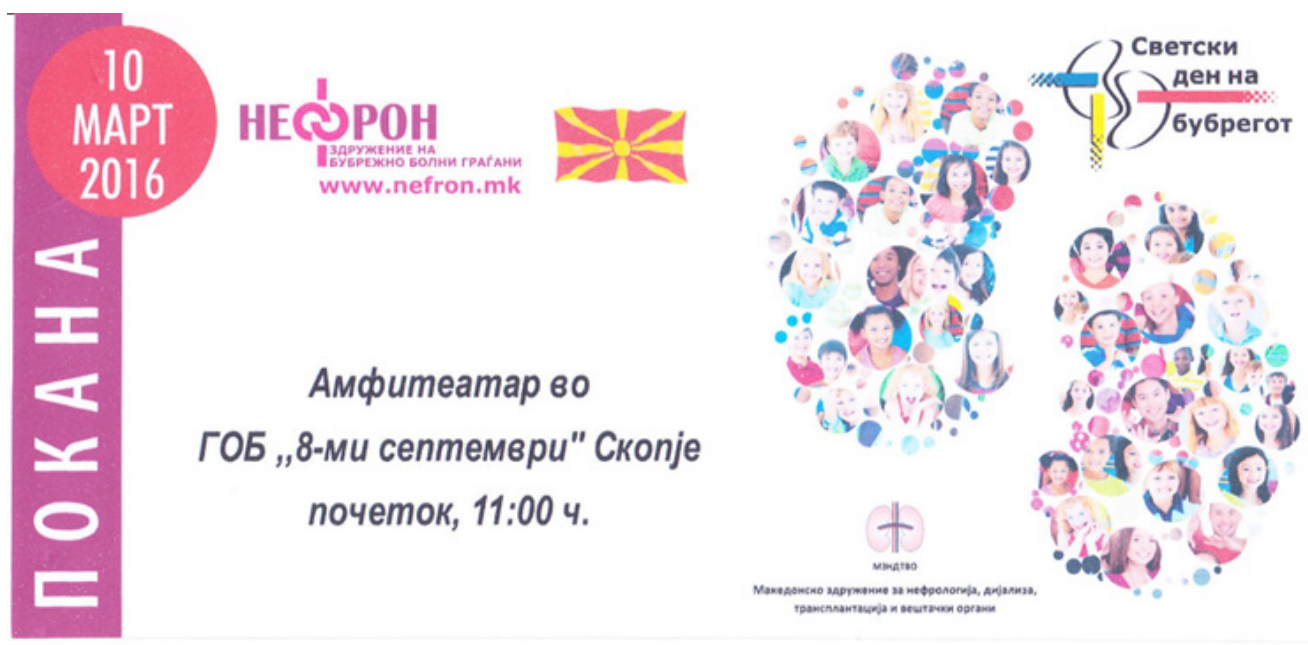

Fig. 15. WKD 2016
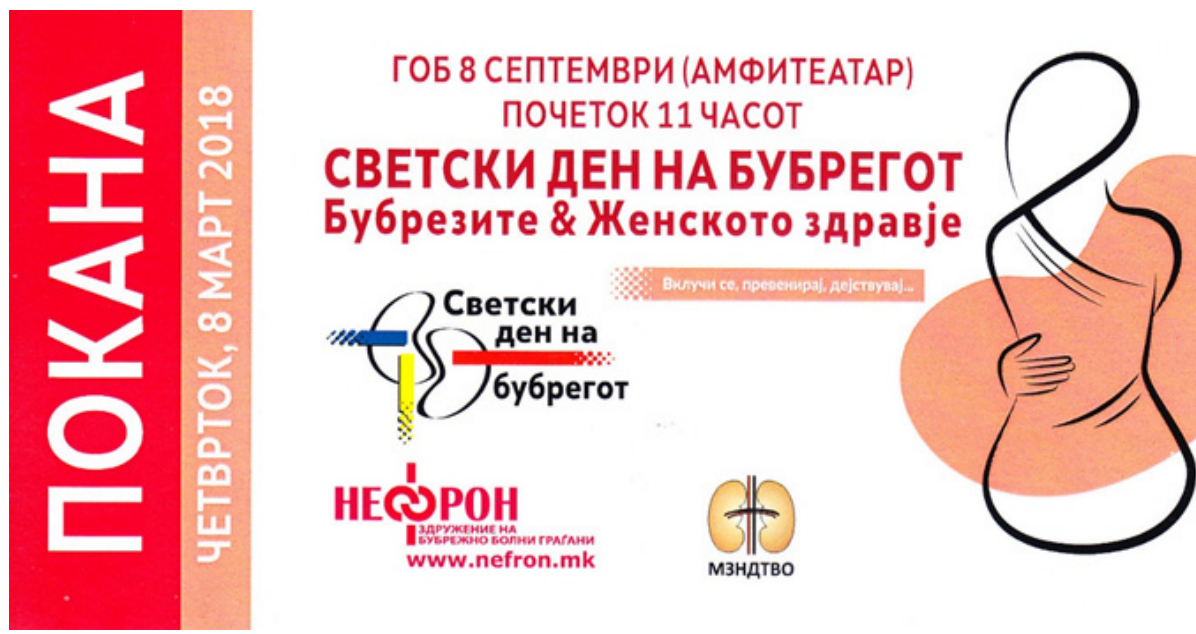

Fig. 16. WKD 2018 
Светскиот ден на бубрезите е најодбележуван настан во светот кој се фокусира на здравјето на бубрезите.

Во март 2018 година Светскиот ден на бубрезите и Мегународниот ден на жената се одбележуваат на ист ден, нудејќи ни можност да размислиме и апелираме до сите жени и девојки од светот за важноста на нивното здравје, посебно за грижата и здравјето на бубрезите кај жената.
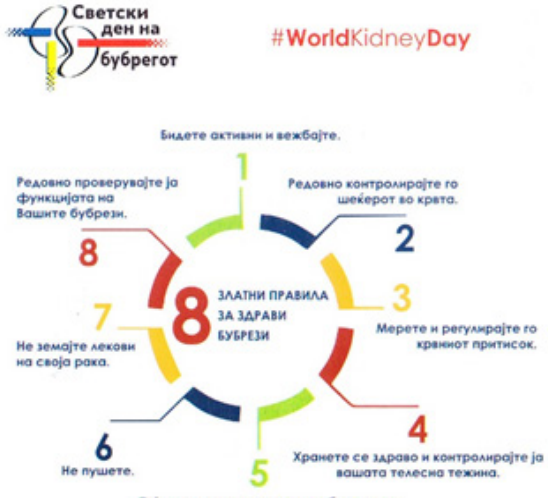

5

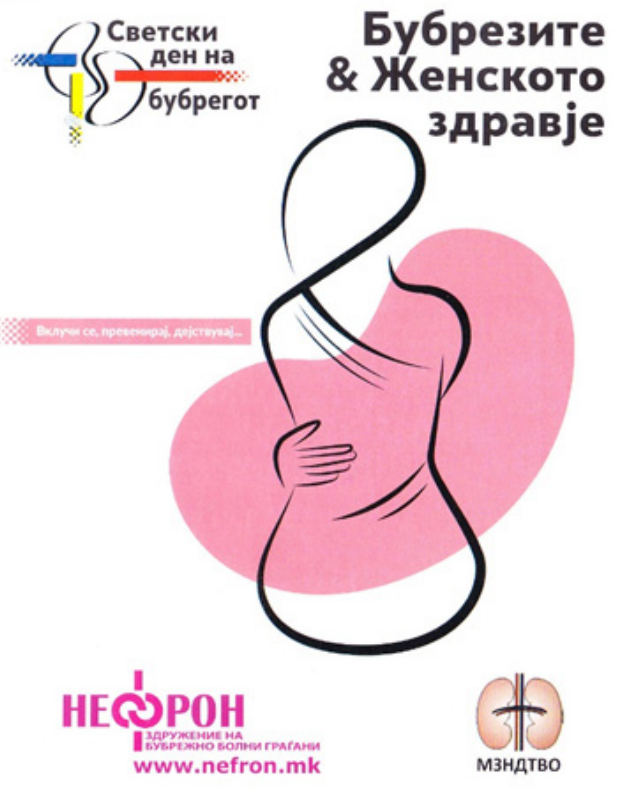

ISN

Хроничната бубрежна болест (ХББ) е светски јавно-здравствен проблем со несакани последици на бубрежна инсуфициенција, дури и предвремена смрт.

ХББ зафаќа околу 195 милиони жени ширум светот .

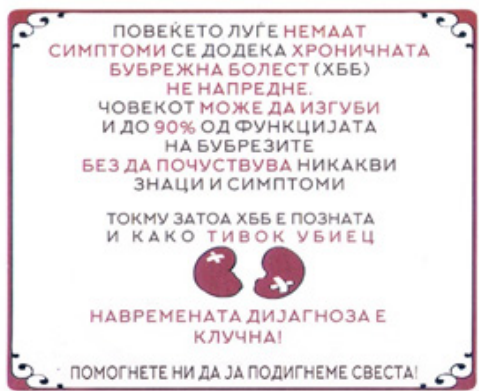

Возрасни имаат хронична бубрежна болест (ХББ). ХББ е една од најбрзорастечките болести во светот. ХББ Не е Ретка Болест.

Во Република Македонија има 1.600 пациенти со краен стадиум на ХББ. Од нив 1.350 се на редовен третман на дијализа, а околу 250 пациенти се со трансплантиран бубрег.

Секоја година нови 300 пациенти започнуваат со терапија. Од нив 170 се мажи, додека 130 се жени.

РЕГУЛАРНАДИЈАЛИЗАИ УСПЕШНА

ХББ е 8-та водечка причина за смрт кај жените , со годишно околу 600000 смртни случаи.

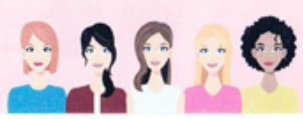

Fig. 17. WKD 2018 
In conclusion, we could say the continuous activities during the WKD contributed to the improvement of the nephrological care and protection of the citizens of the Republic of N. Macedonia.

Acknowledgement to Goce Aleksoski for the technical assistance.

The paper is part of the project "History of Nephrology in North Macedonia", funded by the

Macedonian Academy of Sciences and Arts.

\section{REFERENCES}

1. https://www.worldkidneyday.org/2020-campaign.

2. https://www.worldkidneyday.org/about/worldkidney-day/.

3. S. Naicker et al. The Novel Corona-VIRUS 2019 epidemic and kidneys. Kidney International (2020) 97, 824-828.

4. Y. Cheng et al. Kidney disease is associated with in-hospital death of patients with COVID-19. Kidney International (2020) 97, 829-838.

5. https://www.worldkidneyday.org/2021-campaign/2021-wkd-theme/.

6. M. Polenakovic. Artificial Organs 2000 ESAO

Pri (Contributions), 2020, 41 3; 77-90. 


\title{
Резиме
}

\section{ВАЖНОСТА НА СВЕТСКИОТ ДЕН НА БУБРЕЗИТЕ СВЕТСКИ ДЕН НА БУБРЕЗИТЕ - 11 МАРТ 2021 ГОДИНА - ДА СЕ ЖИВЕЕ ДОБРО СО БУБРЕЖНА БОЛЕСТ}

\author{
Момир Х. Поленаковиќ ${ }^{1}$, Сашо Дохчев ${ }^{2}$, \\ Ирена Рамбабова-Бушлетиќ 3 , Душко Ѓорѓ́евски ${ }^{4}$, Гоце Спасовски ${ }^{3}$ \\ ${ }^{1}$ Македонска академија на науките и уметностите Скопје, РС Македонија \\ ${ }^{2}$ Клиника за урологија, Медицински факултет, Универзитет „Св. Кирил и Методиј“, \\ Скопје, РС Македонија \\ ${ }^{3}$ Клиника за нефрологија, Медицински факултет, Универзитет „Св. Кирил и Методиј“, \\ Скопје, РС Македонија \\ 4 Здружение на бубрежни пациенти „Нефрон“, Скопје, РС Македонија
}

Светскиот ден на бубрезите (СДБ) е глобална кампања за подигнување на свеста за важноста на нашите бубрези за целокупното здравје и за намалување на зачестеноста и влијанието на бубрежните заболувања и придружните здравствени проблеми во светот. Бубрежната болест е незаразна болест и моментално засега околу 850 милиони луѓе во светот. Секој десетти возрасен човек има хронична бубрежна болест (ХББ). Глобалниот товар на ХББ се зголемува и се предвидува да стане петта најчеста причина за изгубени години од животот на глобално ниво до 2040 година. ХББ е главната причина за катастрофалните здравствени трошоци. Трошоците за дијализа и трансплантација се 2-3\% од годишниот буџет за здравствена заштита во земјите со високи примања. Од клучно значење е што може да се спречи заболувањето на бубрезите и да се одложи прогресијата кон последната фаза на заболување на бубрезите со соодветен пристап до основната дијагностика и раниот третман. Оваа година Светскиот ден на бубрезите продолжува да ја подигнува свеста за зголемениот товар на болестите на бубрезите во светот и стремење кон здравјето на бубрезите за секого, насекаде. За време на пандемијата со КОВИД 19 на пациентите им се оштетени и бубрезите, освен респираторниот тракт и другите органи. Тоа може да доведе до зголемување на акутната бубрежна инсуфициенција и хроничната бубрежна инсуфициенција и смрт. Затоа, важно е да се иследи бубрежната функција кај секој пациент со вирусот КОВИД 19. Во РС Македонија од 2006 година до денес нефролозите и другиот медицински персонал посветен на раната дијагноза, превенција и третман на бубрежни заболувања учествуваа во активностите на Светскиот ден на бубрезите. Овие активности беа поддржани од Македонското друштво за нефрологија, дијализа, трансплантација и вештачки органи, Клиниката за нефрологија на Медицинскиот факултет, Македонската академија на науките и уметностите, Владата на РС Македонија, невладините нефролошки организации (НЕФРОН ) и од медиумите. Имаше предавања и презентации посветени на темата на СДБ, публикации во списанија, како и активности за испитување на бубрежната функција на пациентите во медицинските центри. Активностите за време на СДБ придонесоа за подобрување на нефролошката заштита на граѓaните на РС Македонија..

Клучни зборови: Светски ден на бубрезите, бубрежна болест, рано дијагностицирање, превенција, терапија 